\title{
Procedure for Preparation of Financial Statements at The Regional Financial and Assets Agency (BPKAD) in Banten Province
}

\author{
Nida Amalia ${ }^{1^{*}}$ \\ ${ }^{1}$ University of Sultan Ageng Tirtayasa, Indonesia \\ Coresponding Author: nidaamalia2@gmail.com ${ }^{\left.1^{*}\right)}$
}

Keywords : Regional accounting, State accountability, Local government financial reports, System

\begin{abstract}
:
The purpose of this research is to find out the application of regional accounting in preparing BPKAD Financial Reports in Banten Province, to find out what obstacles often occur in the financial reporting process at the Regional Financial and Asset Management Agency (BPKAD) in Banten Province. The results showed that the Financial Statements produced by the Regional Financial and Asset Management Agency (BPKAD) of Banten Province consisted of Budget Realization Reports (LRA), Operational Reports (LO), Balance Sheets, Changes in Equity Reports. In preparing the financial statements, the Regional Financial and Asset Management Agency (BPKAD) of Banten Province has prepared its financial reports properly based on Government Regulation No. 71 of 2010. The advantage of SIMRAL Finance is to facilitate the process of preparing financial reports by inputting data in the SIMRAL Finance application.
\end{abstract}




\section{Introduction}

In the current era, rapid technological advances require various groups to make changes, especially in terms of meeting information needs. For entrepreneurs, formal and non-formal institutions, financial information is very necessary for making economic decisions quickly, precisely and accurately. Accounting is a business tool used by companies in conveying the results of financial information for a certain period. Financial transactions are processed in such a way as to produce a ready-to-use financial report.

According to Halim (2012), public sector accounting can be defined as "a process of identifying, measuring, recording and reporting economic (financial) transactions of an organization or public entity such as the government. Non-Governmental Organizations (NGOs), and others that are used as information in the context of making economic decisions by parties who need it". Since the 1998 revolution, the government has tried to make changes in all fields, including government accounting. Changes in the field of accounting are important because accounting will produce a report that is useful for certain parties in making decisions.

Regional financial accounting is one of the fields in accounting that has received great attention from various parties since the accounting reform in Indonesia which began with the issuance of a package of state finance legislation consisting of: Law No. 17 of 2003 concerning State Finances, Law No. 1 of 2004 concerning State Treasury, Law No. 15 of 2004 concerning Audit of State Finance Management and Responsibility and Law No. 33 of 2004 concerning Financial Balance Between Central Government and Local Government.

Of the four regulations that have been established by the Indonesian government, it is hoped that the management of state and regional finances can be managed more efficiently, economically and effectively so that the results from the use of funds made by the government are more appropriately accountable to the public (accountability) and more open to the public. (transparency). This objective is in accordance with Law No. 17 of 2003 concerning State Finance Article 3 paragraph (1) which reads: "Finance is managed in an orderly manner, obeys the government's laws and regulations, is efficient, economical, effective, transparent and accountable with pay attention to the sense of justice and propriety". In 2010 the Government of Indonesia issued a new regulation in the form of Government Regulation Number 71 of 2010 concerning Accrual-based Government Accounting Standards. This regulation regulates that every government entity, both reporting entity and accounting entity, is required to apply accrual-based SAP in the preparation of financial statements. As mandated by Government Regulation No. 71 of 2010 concerning Government Accounting Standards article 4 paragraph (1) which reads: "The government applies accrual-based SAP"

To carry out regional government accounting, regional heads establish a regional government accounting system with reference to regional regulations on the points of regional financial management, while from the government accounting system a reporting entity is determined and the entity according to the provisions of the legislation is required to submit a report. Accountability in the form of financial statements at the end of the period. The full implementation of regional autonomy brings logical consequences in the form of implementing government administration and development based on sound financial reports 
and the Government has the authority to establish a regional financial management system in the form of Regional Regulations. The system is very necessary in fulfilling the obligations of the local government concerned. Related to regional financial management. The Regional Government at the beginning of each fiscal year stipulates the Regional Revenue and Expenditure Budget (APBD) which is a description of the regional revenue and expenditure plan for one fiscal year. Furthermore, at the end of each fiscal year, local governments are required to compile financial reports as a form of accountability for a one-year period.

The Regional Financial and Asset Management Revenue Agency of Banten Province in an effort to realize transparency, accountability, and regional financial management in an effort to realize that is to submit government financial reports that meet the principles on time and are prepared by following the Government Accounting Standards (SAP), which are generally accepted. The quality of information in the government's financial statements is strongly influenced by compliance with accounting standards and is supported by a reliable accounting system. Therefore, a set of regulations was issued to develop a Regional Financial Management Information System as an effort to present the financial reports of the Banten provincial government quickly, accurately, and accountably.

That in the Regional Regulation concerning the Regional Revenue and Expenditure Budget for the 2019 Fiscal Year as the embodiment of the 2019 Regional Government Work Plan which is translated into the General Policy of the Regional Revenue and Expenditure Budget, as well as the Priority and Temporary Budget Ceiling which have been mutually agreed between the Banten Provincial Government and the House of Representatives Regional People on November 3, 2019. Financial financial statements are a tool used to convey financial information of a business entity. Financial statements are prepared with the aim of providing information regarding financial position, performance and changes in financial position that are useful for various parties who have interests such as: Government Agencies, Managers, Investors, and Creditors in making economic decisions (Darmanto,

The Government Accounting System in local governments is regulated by the Governor/Regent/Mayor regulation which refers to the general guidelines for the Government Accounting System (SAP) regulated in the Minister of Home Affairs Regulation no. 13 of 2006. This regulation is an improvement of Kepmdagri No. 29 of 2002 which contains guidelines for the application of the Regional Financial Accounting System (SAKD). The Regional Financial Accounting System is an improvement from the previous regional financial management system, where SAKD has used the double entry recording method with a modified cash-based accounting system that leads to an accrual basis. Besides, the application of SKPD is also placed in an effort to achieve computerization in government organizations.

In addition, the accountability mechanism for government performance to the public in the preparation of financial reports made at the end of the year, especially in Banten Province refers to the Minister of Home Affairs Regulation No. 64 of 2013 concerning the Implementation of Accrual-Based Government Accounting Standards in Local Governments. The Regional Government Financial reporting system has 2 subsystems, namely the Regional Financial Management Performance Unit (SKPKD) and the Regional Rank Work Unit (SKPD). 
SKPD Financial Reports are a source for preparing SKPKD Financial Statements, therefore each SKPD must prepare Financial Statements as well as possible. The resulting government financial statements must meet the principles of a timely manner and are prepared by following the Government Accounting Standards (SAP) in accordance with government regulation no. 71 of 2010 .

In the local government structure, the Regional Apparatus Work Unit (SKPD) is an accounting entity that has the obligation to record transactions that have the obligation to record transactions of income, expenditure, assets and other than cash that occur within the work unit. In the recording process, it is carried out by the Financial Administration Officers of the Regional Apparatus Work Units (PPK-SKPD) and at the end of the period from the records the PPK-SKPD prepares financial reports for the relevant work units. The Regional Financial and Asset Management Agency (BPKAD) has 2 Reporting entities that record accounting transactions, namely:

a. Transactions carried out by SKPD as a work unit, namely recording financial transactions in implementing programs and activities at BPKAD

b. Transactions carried out by SKPD as local governments to record financial transactions, such as income from balancing funds and grant income, interest spending, subsidy spending, grant spending, social assistance spending, financial aid spending and unexpected expenditures, as well as financing receipts and regional financing expenditures.

In carrying out local government accounting, regional heads establish a local government system with reference to the Banten Governor's Provincial Government Regulation No. 18 of 2014 concerning the Banten Provincial Government Accounting Policy, from the government accounting system a reporting entity and accounting entity are established that implement the regional government accounting system. The reporting entity and the accounting entity according to the provisions of the laws and regulations are required to submit the person in charge in the form of financial statements at the end of the period. The application of the Regional Financial Accounting System (SAKD) is expected to produce more accurate records and reports on financial transactions that occur within local government organizations (entities), appropriate and comprehensive so as to improve the quality of decisions taken by users of the financial statements. In preparing financial statements, one must understand the concept of preparing financial statements and apply government accounting standards (SAP) correctly and appropriately. The preparation and presentation of financial statements that are not in accordance with the rules and standards used in SAP will have an impact on the opinion given by the auditor (in this case BPK) on the financial statements presented.

The Supreme Audit Agency (BPK) stated that local governments should make an activity plan to improve the financial bookkeeping system following the Government Accounting Standards (SAP). In addition, the Financial Audit Board (BPK) can provide an Unqualified Statement (WTP) if there are no errors and irregularities made by the local government, when the auditor conducts an audit, it means that all financial information has been presented adequately. Transparency and the use of finance can be accounted for according to laws and regulations, and free from fraud. If it is not transparent and accountable in certain respects, 
the auditor can give a Qualified Opinion (WDP). If it is not accountable in all respects, the auditor may give an Unfair opinion (TW).

This has happened since the enactment of accrual-based accounting records within the local government environment which must be implemented starting in 2013 in accordance with PP No. 71 of 2010 concerning Government Accounting Standards (SAP) as a substitute for PP. 24 of 2005 which contents require the use of an accrual-based basis for income, expenditure, assets, liabilities, and equity, for 2015. So that the Banten Provincial Government still has obstacles in terms of recording not being carried out properly, the report preparation process is not in accordance with the provisions, inadequate accounting and reporting information system, late submission of reports and the accounting and reporting information system has not been supported by adequate Human Resources (HR).

The Regional Financial and Asset Management Agency (BPKAD) is one of the agencies in Banten Province which is a government institution that is very influential in the Banten government, especially in the Banten Province which always formulates the Regional Revenue and Expenditure Budget (APBD). BPKAD is in charge of carrying out the preparation and technical guidance of accounting and financial data management systems, in implementing government accounting, the Regional Asset Management and Management Agency has implemented computerization as a tool in management, making it easier. As well as accelerating its work so that efficiency, effectiveness, economy and transparency are formed.

The local government in this case the Regional Financial and Asset Management Agency of the Banten Province must be able to design and create a system and accounting procedure for cash that can reduce the risk of embezzlement and misuse of money that is not in accordance with what was previously planned. In addition, an increase in organizational cash, such as that of local governments, belongs to the community, whose existence must be guaranteed. The Banten Province Financial and Asset Management Agency is expected to have an adequate cash receipt system and procedure in order to prevent misuse and fraud, and it is hoped that it can be carried out in an accountable and transparent manner with every existing budget. The purpose of Financial Statement Presentation is to regulate the presentation of general purpose financial statements in order to increase the comparability of financial statements both against budgets, between periods, and between entities. Financial Statements for general purposes are financial reports that are intended to meet the common needs of the majority of report users, including legislative bodies as stipulated in the provisions of laws and regulations.

The existence of regional autonomy indirectly requires local governments to present financial reports in a transparent and precise manner. Local governments are required to be responsible and open to the public in submitting Local Government Financial Reports. Government agencies are required to carry out financial management and be responsible for the implementation of their finances in accordance with their main tasks and functions based on the strategic planning that has been determined. This form of accountability requires the application of an appropriate, clear and measurable financial reporting system in accordance with the principles of transparency and accountability. There is a growing demand for the 
implementation of public accountability to provide information to the public, one of which is accounting information in the form of financial reports

The regional financial report is basically an assertion or statement from the local government management to other parties, namely existing stakeholders about the financial condition of the local government. In order to provide useful and useful information for interested parties, the information presented in financial reporting must meet qualitative characteristics so that it can be used in decision making. The qualitative characteristics of the information in the financial statements can be met with statements that are fairly presented based on generally accepted accounting principles. Therefore, it is necessary to carry out an examination of the financial statements intended to assess the fairness of the financial statements based on generally accepted accounting principles in Indonesia.

To achieve this objective, this standard stipulates all considerations in the context of the presentation of financial statements, guidelines for the structure of financial statements, and minimum requirements for the content of financial statements. Financial statements are prepared using the accrual basis. Recognition, measurement, and disclosure of specific transactions and other events, governed by other government accounting standards.

For the preparation of financial reports in Banten Province itself, using the Planning, Budgeting, and Reporting Management Information System called (SIMRAL) as a form of increasing the effectiveness and optimizing the performance of the Planning and Budgeting Reporting Management Information System in the province of Banten. The Reporting Planning and Budgeting Management Information System (SIMRAL) is an integrated set of tools that is used as a tool to improve the effectiveness of the implementation of various regulations in the field of financial management at the Regional and Asset Financial Management Agency of Banten Province.

Based on the description of the background that has been described above, the authors are interested in conducting research at the Regional Financial and Asset Management Agency (BPKAD) in Banten Province to prepare a final project with the title "PROCEDURE FOR PREPARING FINANCIAL REPORTS AT REGIONAL FINANCIAL AND ASSETS AGENCY (BPKAD) IN BANTEN PROVINCE"

\section{Research Method}

This descriptive analysis consists of general data, namely the profile of the BPKAD (Financial Management Agency and Regional Assets) of Banten Province and special data, namely the discussion of research results on systems and procedures for preparing financial reports at BPKAD Banten Province.

\section{Final Project Writing Object}

The object in writing this final project that I took is the procedure for preparing financial reports for regional financial and asset entities in the province of Banten. With an internship located on Jalan. L. Syech Nawawi Al-Bantani Banten Province Central Government Area (KP3B), Serang City, Banten 42171.

\section{Final Project Writing Method}


The research method is basically a way to get data with a specific purpose and use. To achieve these goals, a method that is relevant to the objectives to be achieved is needed. The method used in writing this final project is descriptive method. Descriptive method is a method of writing about problems in the form of facts that are currently happening, by depicting data, both in the form of tables and graphs, as well as analyzing data by describing or describing the data that has been collected as it is, including the assessment of attitudes or opinions of each individual, organization, circumstances and procedures.

\section{Types and Sources of Data}

The following are the types of data and data sources used in writing the final project report:

\section{Data Type}

In completing this final project, the types of data used in writing this final project are primary data and secondary data. Which have their respective definitions as follows:

\section{a. Primary data}

Primary data is a data source that directly provides data to data collectors. Primary data sources were obtained through interviews with research subjects and by direct observation or observation in the field. Primary data collected in writing this final report is the result of interviews with employees. The primary data is in the form of direct interviews with the head of the Accounting Division at BPKAD Banten Province, namely Mrs. Ella Najla regarding the procedures for Financial Reports at BPKAD

b. Secondary Data

Secondary data is a data source that does not directly provide data to data collectors, for example through other people or through documents. Secondary data is data obtained from a ready-made form that has been collected and processed by other parties, usually in the form of publications. The data requested is general data such as personnel data and data specifically related to research on financial reporting procedures at the Banten Province BPKAD.

\section{Data source}

Data sources are sources from which data is obtained or collected. The source of data used in the preparation of this final project is internal data. In this study, internal data can be obtained from the Accounting section and also in the Financial Statements section. In completing this final report the author uses data sources to support research. Data sources are sources from which data is obtained or collected. Sources of data that will be used by the author in this final report are as follows:

a. Field Study

To collect data sources, the author conducted a field study directly to the company, namely the Regional Financial and Asset Management Agency (BPKAD) of Banten Province. By conducting a field study the author uses the 
method of interview, observation, and documentation in collecting data sources.

b. Literature review

In addition to conducting field studies in collecting data sources, the author also conducts literature studies in collecting data sources, activities in conducting library studies are studying, exploring, and citing theories or concepts from a number of institutions such as books, journals, articles, or other final projects that are relevant to the focus topic being discussed

\section{Method of collecting data}

This descriptive analysis technique consists of general data, namely the profile of the BKAD (Financial Agency and Regional Assets) of Banten Province and special data, namely the discussion of research results on systems and procedures for preparing financial reports at the Banten Province BKAD. namely taking samples from the population based on a criterion in the form of considerations. The samples of this research are employees who work as sub-heads of accounting and reporting, head of accounting section, head of reporting section, head of monitoring section and accounting and reporting staff at BPKAD in Banten Province.

Some of the data collection methods used by the author in compiling the final project are:

1. Observation Method:

The observation method is used to obtain data sources directly and systematically record the object to be studied. Observations made by the author by means of observation and recording of financial statements using the SIMDA application in Banten Province. with the author doing an internship for 1 month at BPKAD Banten Province.

2. Literature Study Method

The library study method is carried out by collecting, reading, studying, and reviewing books and various other sources such as regional government regulations, internet, articles, and lecture materials that have direct or indirect relevance to the subject matter. in order to gain a deep understanding of the concepts and theoretical basis of the discussion as the basis for writing reports

\section{Place and Time of Final Project Research}

\section{Research Place}

Regional Financial and Asset Management Agency (BPKAD) in Banten Province. Who resides on Jalan. Syech Nawawi Al-Bantani Central Government Area of Banten Province (KP3B), Serang City, Banten

\section{Final Project Research Time}

The time of the study began on January 2, 2020 until February 16, 2020.

BPKAD in Banten Province is open at 06.30 - finished 


\section{Field of Practical Work Implementation}

The field of implementation of practical work carried out for approximately one month, more authors were placed on the Regional Financial and Asset Management Agency (BPKAD) in Banten Province, especially in the Accounting section. In the implementation of the practical work, the authors were given directions regarding the Main Tasks of the Agency which were divided into several people in it, were given an explanation of how the recording was applied to the government and was given learning and practical application as well as inputting data from each office and service. -related agencies into the Regional Financial Management Information System (SIMRAL).

\section{Results and Discussion}

1. Procedure for Preparation of Financial Statements at BPKAD in Banten Province

In discussing the financial reporting process that has been carried out by the Regional Financial and Asset Management Agency of the Banten Province BPKAD, the entire series of activities for inputting, recording, managing financial statements based on the type of Financial Statements. The procedure for preparing the Financial Statements of the Banten Province BPKAD which aims to determine the smoothness and achievement of the goals of an organization, create good supervision, show the determination of the responsibilities and targets that have been set, it is necessary to develop and implement appropriate strategies that are in line with regional policies. To determine the key success factors supported by valid and relevant data by taking into account the existing conditions and capabilities. 


\section{PREPARATION OF FINANCIAL STATEMENTS FOR THE PROVINCE}

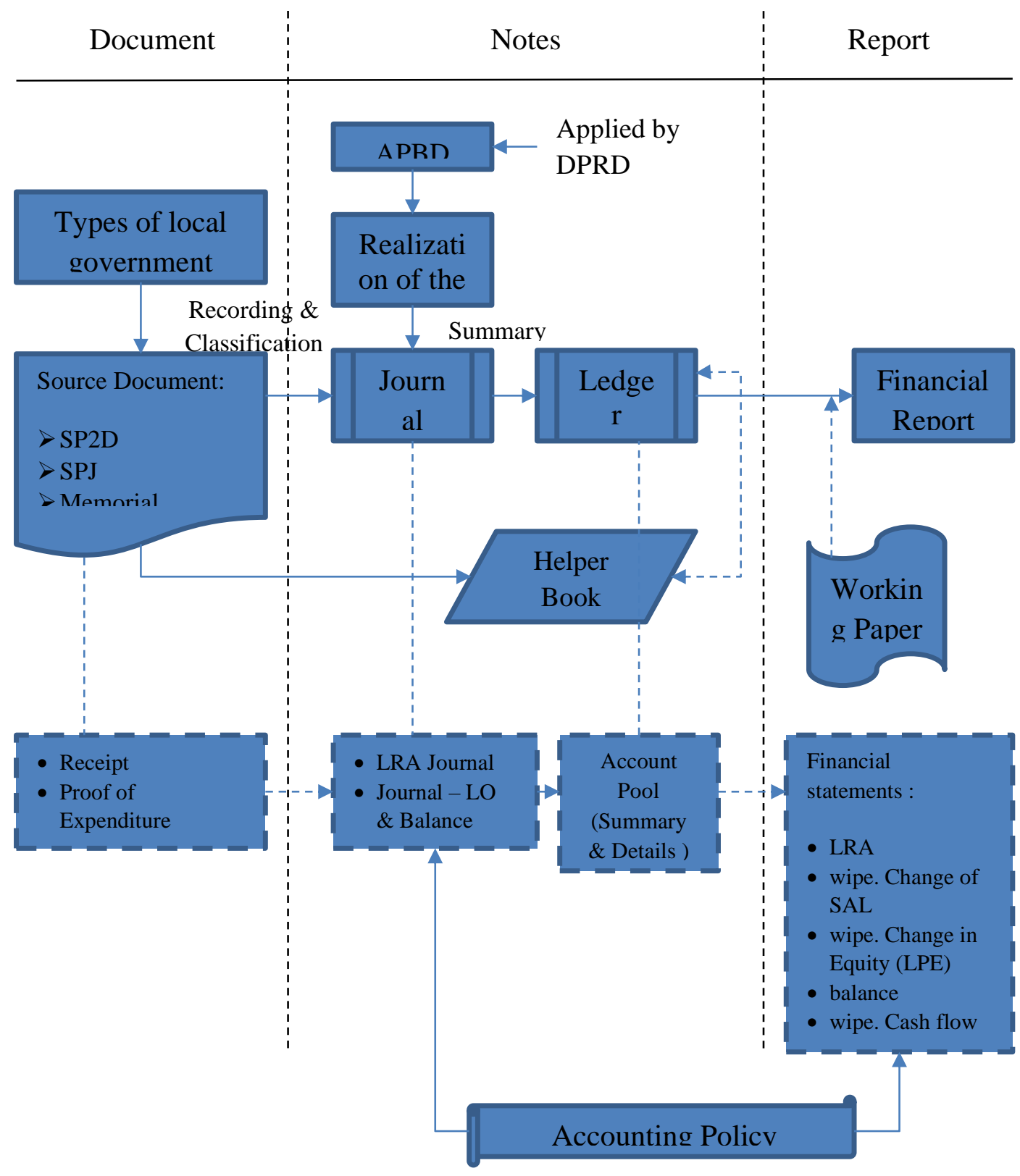

Figure 1. Flowchart of Financial Statement Preparation

The first stage, the financial report begins with the government's financial budget transactions determined by the Council. Then there are two types of entities in the preparation of the Banten Province Regional Financial Statements, namely accounting entities and reporting entities, therefore BPKAD must merge/consolidate each SKPD. Then the transactions at the beginning are recorded chronologically in the journal before being transferred to the general ledger. The transaction includes the date, account name and description. Thus there are types of journals, namely Budget Realization Reports, Operational Reports and Balance Sheets. 
Then, the transactions that have been recorded are then clarified into the Ledger per account account code. Next, compile the Balance Sheet for each account or account code from the general ledger and then summarized in the Trial Balance. Based on the Trial Balance in identifying the accounts included in the Budget Realization component, the Operational component then moves it into the Realization Report and Budget Operational Report. Then the SKPD makes adjusting journals by making balances in certain accounts and recognizing accrual transactions. SKPD makes adjustments to the Balance After Adjustment. Then Prepare Financial Reports.

The preparation of SKPD Financial Statements through the accounting process carried out by each Banten Provincial government agency to be the basis for preparing financial reports which will be sent to BPKAD to import each SKPD on the Financial Statements.

2. What are the obstacles that often occur in conducting financial reports at BPKAD in Banten Province

Based on the results of research on the procedures for preparing financial statements at BPKAD in Banten Province. There are several obstacles faced when preparing financial statements, namely:

a) From Human resources personnel who work in BPKAD in the field of accounting, not all employees are experts in the field of government accounting. If there is an error during the financial reporting process, this will make the results of the financial statements not completed on time, because not all employees are experts in the field of accounting. The solution is for BPKAD employees who are not experts in accounting and for new employees to be given training related to accounting

b) Making Financial Reports also has limited time. At the beginning of each year, the Supreme Audit Agency (BPK) will begin to audit local government financial statements, especially in the form of collecting the necessary data. The local government is very interested in the audit because in recent years, the Ministry of Finance has implemented a reward and punishment system for local governments. There are three kinds of criteria in the system, namely the region has carried out its community service function well, the region determines the APBD in a timely manner and the regional government financial report (LKPD) obtains an unqualified opinion (WTP) from the BPK. If the local government implements these three criteria well, it will get additional incentives. However, if the local government is unable to implement these criteria properly, it will lead to sanctions from the Ministry of Finance, especially financial sanctions. The solution is to tighten supervision to agencies in the formation of financial reports so that errors do not occur in making financial reports and avoid delays in the allotted time.

\section{Conclusion}

Based on the results of research and discussion obtained during real work practices at BPKAD Banten Province regarding the procedures for preparing Financial Statements at BPKAD Banten Province, the authors can conclude that, among others, as follows: 
1. The Financial Report produced by the Regional Financial and Asset Management Agency (BPKAD) of Banten Province consists of the Budget Realization Report (LRA), Operational Report (LO), Balance Sheet, Report on Changes in Equity. In preparing the financial statements, the Regional Financial and Asset Management Agency (BPKAD) of Banten Province has prepared its financial reports properly based on Government Regulation No. 71 of 2010

2. SIMRAL Finance is an application formed by the Central Government with the aim of realizing quality state financial accountability in the central government towards a more effective government. The advantage of SIMRAL Finance is to facilitate the process of preparing financial reports by inputting data in the SIMRAL Finance application.

\section{Acknowledgment}

Acknowledgments are conveyed to the Diploma Three Accounting Study Program, Faculty of Economics and Business, University of Sultan Ageng Tirtayasa.

\section{Reference}

Provincial Financial and Asset Management Agency 2019: Financial Report. Serang: Regional Financial and Asset Management Agency:https://bpkad.bantenprov.go.id/ (accessed on April 20, 2020, at 13.30 WIB)

Baridwan, Zaki. 2010. Accounting System Preparation of Procedures and Methods, Edition 5. Yogyakarta: BPEE

Dina, Fitria. 2014. Smart Book of Accounting for Lay People and Beginners. East Jakarta: Laskar Aksara

Halim, Abdul. 2012. Public Sector Accounting: Regional Financial Accounting Edition 4. South Jakarta: Salemba Empat

Indonesian Accounting Association. 2019. Explaining Government Implementing AccrualBased SAP. Jakarta: Indonesian Accounting Association. (https://iaiglobal.or.id accessed on 21 April 2020, 18:30)

Kieso E Donald, Weygant J Jerry and Warfield D Terry. 2018. Introduction to Accounting 1 Based on IFRS. Jakarta: Salemba Empat

Mulyadi. 2010. Accounting System Edition 3. DKI Jakarta: Salemba Empat

Planning Management Information System, Regional Budgeting (SIMRAL): https://simral.bantenprov.go.id/ (accessed April 20, 2020, 10.30 WIB)

Sudarmanto. 2015. Performance and Competency Development of Human Resources Edition 3. Yogyakarta: Pustaka Pelajar

2010. Government Regulation of the Republic of Indonesia Number 71 of 2010 concerning Government Accounting Standards. Jakarta 
2018. Banten Province Regional Regulation Number 9 of 2018 concerning Regional Revenue and Expenditure Budgets for Fiscal Year 2019. Serang

. 2006. Regulation of the Minister of Home Affairs of the Republic of Indonesia Number 13 of 2006 concerning Regional Financial Management Guidelines. Jakarta

2018. Regulation of the Governor of Banten Number 18 of 2018 concerning the Accounting Policy of the Banten Provincial Government. attack

. 2005. Government Regulation of the Republic of Indonesia Number 24 of 2005 concerning Government Accounting Standards. Jakarta

2003. Law of the Republic of Indonesia Number 17 of 2003 concerning State Finance. Jakarta

2004. Law of the Republic of Indonesia Number 1 of 2004 concerning the State Treasury. Jakarta

.2004. Law of the Republic of Indonesia Number 15 of 2004 concerning Audit of State Finance Management and Responsibility. Jakarta

.2004. Law of the Republic of Indonesia Number 33 of 2004 concerning Financial Balance between the Central Government and Regional Governments. Jakarta. 